\title{
Euripides' Andromache and the Dynamics of Philia
}

\author{
Kata Pártay \\ (Eötvös Loránd University, Budapest)
}

\begin{abstract}
In the present paper, through the analysis of the different meanings of philia in Andromache, I wish to show how Euripides makes use of the polysemy of the term in his play. There is no consensus among scholars of Ancient Greek about the exact meaning of the word philos or other related expressions such as philein and philia. It seems apparent, however, that the use of these terms went through significant changes from the time of Homer to the fifth century. In classical Athens, the term could take on different meanings depending on the situation it was used in, sometimes denoting emotional relationships based on personal feelings and attitudes, sometimes referring to socially regulated, politically influenced ones. Through a close reading of those passages of Andromache which deal with the situation of Andromache in the oikos of Neoptolemus, I would like to demonstrate that the interpretation of the terms signifying family relationships and friendships are especially prone to change depending on the speaker's current situation and aims. The main conflict of the play revolves around the status of Andromache and most of the cases in which the term philos is used are connected to Andromache, therefore it seems justified to concentrate on the question of who is or might be regarded as her philos. The characters manipulate and distort the meaning of the word to serve their own purposes. My suggestion is that Euripides uses conflicting concepts of philia which belong to different codes of behaviour and sets of values and by doing so reveals the inherent tensions in some of the terms and concepts which were prevalent in fifth-century Athens.
\end{abstract}

\section{Keywords}

Euripides; Athenian tragedy; family relationships; marriage; philia 
The concept of philia plays an unquestionably important role in Greek tragedy. Suffering caused by a philos or violence among philoi are usually part of the tragedies' plot. Aristotle says in the Poetics that the plots which most effectively arouse pity and fear are those that include violent acts against philoi. ${ }^{1}$ Unfortunately for later critics, he does not define the exact group of people who count as one's philoi. ${ }^{2}$ Are they just family or family and friends? Are subjective sympathy, love and friendship the criteria for the bond of philia or is it a more objectively regulated social institution? The precise definition of the semantic field of philos and its related verb philein is problematical not only concerning fifth century literature, but already in the Homeric epics. The usage of the term clearly goes through some changes in the course of the centuries: it gains an element of personal affection that seems to be lacking in Homer. In this paper, I argue that it is not just critics who are somewhat puzzled by the term, but there was an inherent polysemy in the meaning and use of the word philos (and of related terms such as philein and philia) in the fifth century, and that Euripides made use of this polysemy in Andromache. First, I very briefly address the problems which are recurrent in debates regarding the exact meaning of philos, then through the analysis of certain passages of the Andromache, I aim to show how the characters of the play dynamically construct and reconstruct the meaning of these terms to support their arguments, or to strengthen their position in the family. The most debated question in the play regards the status of Andromache in Neoptolemus' household, therefore I would concentrate now on the question whether she can be regarded as a philos of the king.

There are two interconnected problems regarding the use of the words philos and philein in Homeric epics that are important for our perception of philia in the Andromache. One is the question of whether the terms contain a semantic element of personal affection. ${ }^{3}$ The other has to do with the degree to which these terms denote socially regulated institutions. ${ }^{4}$ One aspect which most of the critics agree on is that in the Homeric epics philein - regardless of whether it involves sympathy or affection - requires acts of help and active alliance. ${ }^{5}$ To be one's philos is to give him (or her?) ${ }^{6}$ help

1 Arist. Po. 1453b14-22.

2 See Belfiore (2000: pp. 4-9).

3 Adkins (1963) and Benveniste (1969) gave very influential analyses of the term, both critics emphasize that although emotion might be a part of the meaning, it is not essential. Others, however, argue for the element of personal affection. See Hooker (1987), Robinson (1990), and Konstan (1997).

4 For a review of the different views on the meaning of the word philos in Homer see Spahn (2006: pp. $165-175)$.

5 "To render other human beings his philoi, the agathos must of course benefit them; and this activity is philein, a word conventionally rendered 'like', 'love', 'receive hospitably'. Philein requires action and results rather than emotions or intentions: a familiar situation in Homeric society." Adkins (1972: p. 17). On the connection between philia and other aspects of the heroic values see also Scott (1982), Taillardat (1982), Spahn (2006: pp. 165-175).

6 Adkins (1963) argues that philos and philein are fundamentally important aspects of the epic heroes' values, and can only be used in relation to the agathos as their subject. Therefore, women can be one's philos but cannot have philoi on their own right. 
in need. The cooperative ${ }^{7}$ nature of the concept is part of the ethical framework of the heroic world depicted in the epics. ${ }^{8}$ By the fifth century, the range of people and things that can be one's philos seems to be wider than in Homer. A political-ethical meaning is still prevalent, but by this time, subjective sympathy or love can definitely play a part in the word's use. Philia and xenia ${ }^{9}$ are related to each other, but social regulations seem to be somewhat looser or more contradictory. ${ }^{10}$ As Schein puts it: "Between the time of Homer and the final third of the fifth century, there were two main developments in the meaning of philia: 1) a fundamentally instrumental notion, which had been part of a more general, traditional concept of reciprocal solidarity, became the primary sense of the word; 2) a word that originally signified a social and later, a political institution came to be used more often of individual, affective relationships". ${ }^{11}$ In the tragedies of Euripides, the word can take on very different, sometimes contradictory meanings. ${ }^{12}$ In Electra, there is an emblematic passage which demonstrates the contradictions the term allows

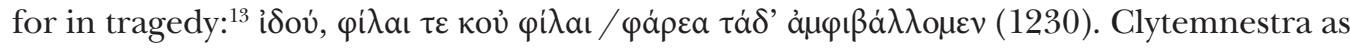
the mother of Electra is necessarily phila to her but she is not phila in terms of a loving relationship. The two aspects of the same word clash with each other in one sentence in a typically Euripidean way.

In the Andromache, a play particularly focusing on marriage and kinship, there are more than twenty occurrences of the word. It denotes a friendly, casual relationship between loosely connected people or even between slave and master (e.g. 87, 818-819, 1051). It is used for family ties established by marriage (e.g. 376, 641, 644), denotes cities that are each other's allies $(734,890)$, refers to family members who live in the same household (e.g. 986), and in one passage it appears to be used for a formal xenia relationship (1068). The mere list of different uses already demonstrates that the meaning

7 Cooperative compared to other, competitive aspects of heroic life. Adkins (1963: p. 37) prefers to call philotes reciprocal rather than cooperative.

8 The term philia is not yet present in Homer, I use the word here as it was used later, as a synonym of philotes.

9 Benveniste (1969: pp. 335-353) argues that in the Homeric epics philia and xenia are strongly connected. Taillardat (1982) claims that the rites of hospitality are at the root of the term. Although the etymology of philos remains debated, the connection between philia and xenia is strong. In Euripides' oeuvre the Alkestis problematizes the responsibilities towards philoi and xenoi. On philia in the Alkestis see Stanton (1990) and Schein (1988). In Andromache, however, the concept of xenia meant as hospitality or guest-frendship does not seem to be of much relevance. The characters portrayed belong to families between which there are no ties of xenia, and the word xenos is only applied in the sense of 'foreign' and 'alien'. In lines 136 and

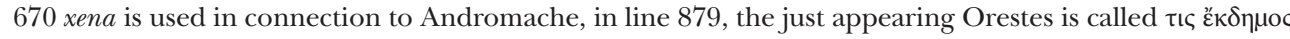

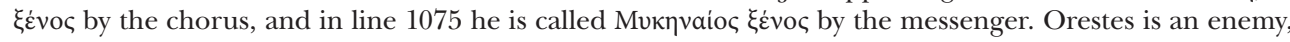
and for the chorus Andromache is a foreigner.

10 Konstan (1996 and 1997) claims that the noun ho philos cannot mean family member neither political ally, only friend in a sense quite similar to that of the English term.

11 Schein (1990: p. 59). See also Stanton (1995) on conflicting interests of philia in Hecuba, and Mueller (2001) on the connection between charis and philia, and on the different ways in which Medea uses the codes of aristocratic values and the language of reciprocity in Medea for her own purposes.

12 On the different aspects of the meaning of philos in Euripidean tragedies see Perdicoyianni (1996).

13 For the analysis of philia in Electra see Konstan (1985). 
of philos and philia is not limited to one strict category of interpersonal ties, and that politically, personally and socially motivated uses are all common in the tragedy. It also suggests that philia does not have a strong normative power to ascribe certain forms of behaviour as it does in Homer. However, a closer look at the contexts, in which philiarelated terms are used, helps us to assess the motivation lying behind each case. As there is no place here for examining all the contexts in which philia is used in the tragedy, ${ }^{14}$ I will focus on one central theme, that of the status of Andromache in Neoptolemus' oikos and the implications that the different interpretations of the range of philia have on her and her son's status. The most debated and unclear question in the play is whether Andromache can claim to be a philos to anyone in Phthia. The horizontal and vertical relationships within and amongst families are of main importance in the development of the play's story. These relationships are not always well defined though, and as the story unfolds, we can see how they lose their stability and undergo frequent re-evaluations.

Andromache is a post-war tragedy in the sense that it depicts the aftermath of the Trojan war and its effects on those who participated in it. ${ }^{15}$ Before turning to the examples, it seems justified, through a summary of the rather complex plot, to outline the narrative context: After the sack of Troy and the death of Hector and Astyanax, ${ }^{16}$ Andromache is given to Neoptolemus as a concubine. Soon she gives birth to a child, ${ }^{17}$ who grows up in the palace, despite the fact that his status as a legitimate child has not been established. Some time after the child has been born, Neoptolemus marries Hermione, but she seems unable to get pregnant, and suspects Andromache of poisoning her in secret, and of turning Neoptolemus away from her. At the beginning of the play, Neoptolemus is in Delphi, trying to reconcile with Apollo whom he earlier accused of Achilles's murder. Taking advantage of his absence, Hermione and her father, Menelaus are planning to kill Andromache and her son. In the prologue, we see Andromache taking refuge at the altar of Thetis and staying there until she is tricked into leaving by Menelaus. Menelaus takes the boy hostage, and is about to kill both mother and son when Peleus arrives and rescues them. In the next main act of the play, the focus moves to Hermione, who is desperate and terrified of Neoptolemus' anticipated future anger. But Neoptolemus never returns home. Instead of him Orestes arrives and rescues Hermione. Later the audience learns from a messenger that he also set a trap for Neoptolemus, whom the people in Delphi, with the help of Apollo, killed. In the exodos, Thetis arrives and establishes new family relationships: she takes Peleus with herself to the sea, and commands the king to make Andromache marry one of the last Trojans, Helenus. The family of Achilles is all dead now, but the bloodline does not disappear completely. The child of Neoptolemus and Andromache survives, and in the future, he will be king of the Molossians.

14 There is one bigger context that will not be examined more thoroughly: Orestes uses the term in a narrower sense than anyone else in the play when he is talking about his perspective on marriage and of the

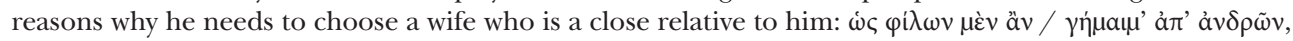

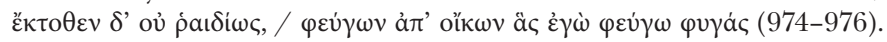

15 Allan (2000: p. 93).

16 The name of his first son does not appear in Andromache's recollection of the story.

17 In the play, he does not have a name, other works call him Molossus. 
As this short summary already demonstrates, the plot of the tragedy is episodic, ${ }^{18}$ and it is not so much a straight storyline that unites the whole, but rather a set of dichotomies and the theme of marriage,$^{19}$ or better to say, the theme of the exchange of women. There are women in the centre of the plot, who function as links between families, ${ }^{20}$ but the kinships they establish seem always somehow dysfunctional. Andromache and Hermione are united to the same $\operatorname{man}^{21}$ - the latter by marriage, the former by giving birth to his child - and yet, both are unable to fully conform to the societal expectations of a wife. Although Hermione is Neoptolemus' lawfully wedded wife, by being barren she is unable to fulfil her most important duty: to bear children to her husband. Andromache, on the other hand, gives birth to Neoptolemus' child, but she, in other respects, is unsuitable to be the wife of a Greek hero. ${ }^{22}$ She does not have the social status, since the lost war she is in the hands of enemies, consequently she is a slave $\mathrm{s}^{23}$ and in the eyes of her rivals a barbarian. ${ }^{24}$ Both Hermione and Andromache are trying to secure their position, ${ }^{25}$ and they do that mostly by manipulating and distorting, to their own advantage, the meaning of philia.

In the prologue, Andromache draws a picture of the current situation that is neatly structured by binary oppositions. ${ }^{26}$ She emphasizes the contrast between her former high social status and her present slave status. Her first words are an evocation of the

18 This structure does not satisfy the Aristotelean criteria of unity, and this fact might be the reason of the play's unpopularity. On open and closed structures in Euripides see Mastronarde (2010: pp. 63-88).

19 There are several papers which argue that marriage is the uniting theme of the play. See among others: Rabinowitz (1984), Padamitropoulos (2006), Kyriakou (1997).

20 Lévi-Strauss (1969) was the first to use the term "exchange of women" in his structuralist anthropology. He writes that in archaic societies marriage is the most effective way to establish new relationships between men. In this system, women only serve as links between men. An important feminist critic of his model is Rubin (1975). On marriage in archaic Greek society see Vernant (1979: pp. 55-78). On marriage and legitimate children in Athens see Just (1989: pp. 28-52), MacDowell (1978: pp. 84-108), further references in notes 34 and 35. On the role of marriage in Greek tragedy a number of influential feminist works have been written in the last decades. Two with similar starting point but different conclusions on the role of women in Greek tragedy are Rabinowitz (1993) and Wohl (1998).

21 Andromache claims in the prologue that after Neoptolemus married Hermione, their sexual relationship ended. However, Hermione does not believe it, and the audience is not given any evidence by which to decide who is telling the truth.

22 Vester (2009: p. 302).

23 For an attempt to interpret slavery as a class in Marxist terms see Rabinowitz (1998: pp. 63-67).

24 It is notable that only Hermione and Menelaus use the term "barbaros", Andromache never calls herself a barbarian, and neither does anyone sympathetic to her, although they all emphasize her foreignness. The barbarian theme is explored by Papadomia (2010: pp. 16-26).

25 Storey (2016: pp. 193-197) suggests that the conflict of Hermione and Andromache is the key theme of the whole play.

26 Prologue monologues are usually considered honest and true in the literature. This tendency can be seen also in Allan's evaluation of Anromache's character. He takes everything Andromache says about her situation at face value, and does not consider the subjective elements of the monologue (Allan 2000: pp. 87-104). On the subjective nature of Euripidean prologues see De Jong (2007: pp. 19-28). Her observations on the subjectivity of messenger speeches also influenced my line of thought here. De Jong (1991: pp. 63-116). 


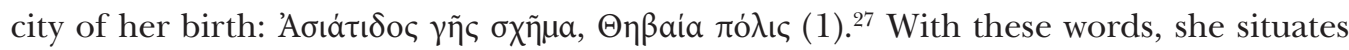
herself in the past and implies that she still identifies herself with her life in Troy. The way she tells her story to the audience emphasizes the differences between the two periods of her life. ${ }^{28}$ She left the house of her father forever when she married Hector, and

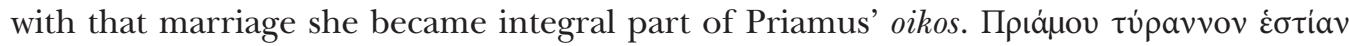
ả underline that she was given away as a wife whose main role was to give birth to children and that she accomplished that goal. After the Trojan war, she was given away again, but

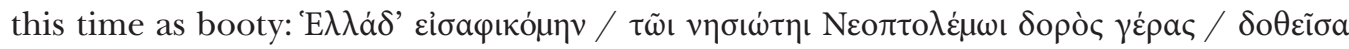
(14-15). The two sentences have very similar structure and vocabulary. In both cases the verb afikneomai stands with the passive participium dotheisa, the place where she arrives is in the accusative, and the man she is given to in the dative. The parallel structure of the two sentences renders parallel her two journeys ${ }^{29}$ to Priam's house and to Hellas, and her relationships with Neoptolemus and with Hector. She also lays emphasis on the distinctively different nature of the relationship she had with Hector, on the one hand, and with Neoptolemus, on the other. Talking about Hector in the prologue and later in the play, Andromache always uses the word posis 'husband' and to herself the word damar 'wife'. When she addresses her relationship with Neoptolemus, she says despotes 'master' and doule 'slave'. In this new situation, the terms damar and gamein suit only Hermione. ${ }^{30}$

The other distinctive comparison Andromache draws is between herself and Hermione. She juxtaposes herself and Hermione in three respects: first, Hermione is a wife, and she is just a concubine. Yet, and this is the second point, she is paidopoios: ${ }^{31}$ she had given children to her husband when she still had him. On the other hand Hermione is barren. And thirdly, she left the house of her father after her marriage, as opposed to Hermione who maintains a strong relationship with her father and her former oikos. In the Homeric poems, the wife becomes part of the oikos of her husband, she does not have a dowry that would guarantee some degree of freedom to her, and any ties between she and her father diminishes. In the fifth century Athens, there are different customs, however. The bride gets a dowry from her father, that she keeps during her marriage, and her ties with her original family remain intact to some degree. In case the pair decides for separation, the husband is obliged to give back the money he has got from the wife's family, and the woman can relatively easily re-marry. ${ }^{32}$ In the play, Andromache's views on marriage are closer to what is present in Homer, while Hermione expresses

27 The interpretation of the word schema is problematic. See Kyriakou (1997: p. 9).

28 The fact that she used to be a queen, but lost her status and with that a part of her identity is connected to the nomos-physis problem. See Lee (1975: pp. 10-11) and Vester (2009: pp. 296-297).

29 In the Andromache, new marriages are connected to movement. The movement of the brides is not just between oikoi but they also move between poleis or in the case of Thetis, between the sphere of the gods and that of humans. On the motive of repeated "bridal processions" see Storey (1989: pp. 19-20).

30 Storey (1989: p. 19).

31 It also emphasizes that her marriage to Hector was legitimate. Vester (2009: p. 296, n. 14).

32 In the case of free, Athenian women. On customs of marriage see Harrison (1968: pp. 45-60), MacDowell (1978: pp. 86-89), Just (1989: pp. 28-52), Silver (2018: pp. 29-33). 
views closer to those in contemporary Athens. ${ }^{33}$ In their conflict, besides the personal factors, different concepts of marriage and of the duties of husband and wife also clash.

While Andromache's status as slave is made very clear in the prologue, the status of her son is more obscure. She does not use any expressions that would make clear the nature of the boy's relationship with Neoptolemus and his situation as his son. It is telling that she does not label Neoptolemus as the boy's pater, only phyteusas and later pater keklemenos. This way she leaves undecided whether the boy is acknowledged by his father or not, and whether he can claim the status of a legitimate heir or he is a nothos. ${ }^{34}$ In the world of the Homeric epics, it was possible that a hero acknowledged his son from a concubine as his legitimate heir. In Athens, especially after the Periclean law in 451/52, an heir could only be born from an Athenian, free woman. ${ }^{35}$ This means that in Homer, a son of a concubine can easily be the philos of his father, but in Athens in the fifth century, it is most likely that he cannot appeal for such a status, neither for the protection that comes with it. In the genre of tragedy, there is no rule for which custom should be followed, but the question of the boy's status in the oikos is crucial in deciding whether he and his mother can be regarded as Neoptolemus' and Peleus' philoi. Andromache says in the prologue that her only hope is her son (27-28). That can be understood as she is deprived of all joy in life, only her motherly love gives her happiness, and her son is the only person who truly belongs to her. On the other hand it also can shed a light on the dependence of her position on that of her son's.

Andromache is a supplicant in a seemingly hopeless situation, therefore she presents her case in unambiguous terms and emphasizes the threats she faces and the calamities she has already suffered in order to achieve sympathy. It is not that she lies, but the way she presents the facts is quite subjective, and as the story unfolds the clear oppositions which she draws prove to be more complicated and problematic. Although she clearly identifies herself as a slave, the other Trojan slave addresses her as despoina (56). ${ }^{36}$ This address is striking at first, but the Therapaina explains that it is the sign of her loyalty (she was Andromache's slave in Troy), and Andromache answers to this loyalty by calling her philtate syndoule (64). She accepts the affection but rejects the address that suggests that she still has power. The adjective philtate prepares for the theme of philia in their dialogue. After telling Andromache the bad news, that Menelaus have captured her son, the Therapaina says with sympathy that if Neoptolemus were there, Menelaus would not dare to threaten Andromache, but now without him being around, she is without philoi.

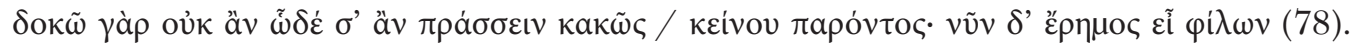
This sentence implicates that if Neoptolemus were at Phthia, Andromache would have philoi. Andromache accepts this implication, and asks if Peleus has recieved her

33 For a comparison of these two types of marriages see Foley (2001: pp. 59-105) with further references.

34 The evidence we have of the specific meaning of nothos mostly comes from the period after the Periclean Citizenship Law, therefore the usage of the term before that is not entirely clear. On the meaning and usage of the word nothos see Ogden (1996: pp. 14-17). For differing views on the legal status of children born to pallakai see Silver (2018: pp. 169-176), Carawan (2008), Sealey (1984).

35 On the implications of the Citizenship Law see Patterson (1990) and the works cited in note 34.

36 It is also a formal technique to show that the new character on the stage is a slave. 
messages. Her answer shows that she believes that she can count not only on Neoptolemus but also on Peleus. She also reveals that she has sent him several messages already.

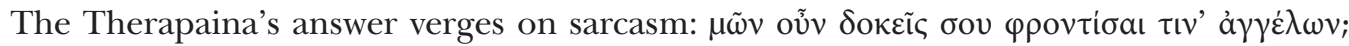
(82) 'You do not think that anyone cares to be your messenger?!' But this is exactly what Andromache has thought. She believed that she has enough power to give commands to the other slaves. Her situation appears to be more complicated than it seemed to be earlier: on one hand, she claims herself to be alien to everyone in Phthia, on the other, she acts as if she had a higher position, from which she can give orders to others. But quickly comes the realization that her hopes were false and she must rely on philia meant as personal sympathy to achieve what she wants. As the Therapaina first refuses to take up the task of a messenger, Andromache employs a new strategy: she appeals to the other's feel-

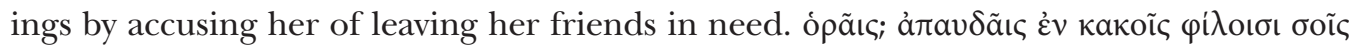
(87), and with this move she pushes the other to do as asked. ${ }^{37}$ The institutional meaning hardly plays a role in this passage, Andromache does not have any other connection with this other slave than emotional, and that is what she evokes by calling her a philos. ${ }^{38}$ The possible implications of the terms are played against each other in these lines. ${ }^{39}$

After the prologue, the audience can learn about the chorus' views on the situation. The chorus consists of free Phthian women who have no personal interest in the conflict between Hermione and Andromache. For them Andromache is a xenos, but their attitude towards her is sympathetic. In the parodos, they repeatedly warn Andromache

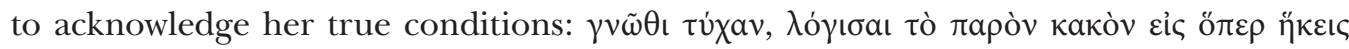

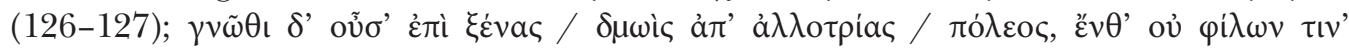

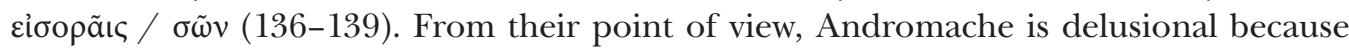
she does not recognize that she is without philoi in Phthia, therefore her supplication is necessarily futile. For the chorus, philia must relate to a certain kind of shared political or "national" identity: a xenos cannot appeal successfully for acts of philia. Although they treat Andromache as alien to themselves, they also seem to accept her as an almost legitimate wife of Neoptolemus. They never call Andromache a barbarian, although they are fully aware of her foreignness. They do not connect her Asian origin with other, negative characteristics, as Hermione and Menelaus do. Once they use the surprising attributive nympha ${ }^{40}$ to her, and later, in the second stasimon when they condemn the situation in which the two competing women found themselves, they phrase it in a way that does

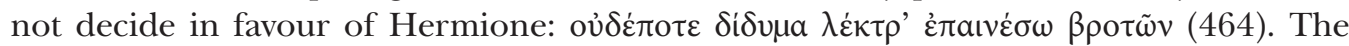
expression didyma lektra portrays the two women in the same position in relation to Ne-

37 It can also be a sign that despite her changed status, Andromache can still employ her former superiority.

38 There is another instance in the tragedy when someone tries to change the other's disposition by calling him philos: Andromache's son calls Menelaus philos in supplication, but Menelaus coldly refuses an emotional answer (540).

39 Torrance (2005: pp. 44-45) sees the dialogue as entirely ironic, and argues that it depicts the other slave's inferiority.

40 Surprising because it is usually used for young women who have just been married or not married yet. The term also appears in connection to Medea (Med. 150). 
optolemus. The chorus uses the words lektron and lechos in the sense of wife, ${ }^{41}$ therefore they do not need to decide who is addressed as damar or gyne, and who is the legitimate partner of their king. Their attitude suggests that the dividing line between Andromache and Hermione is not so clear as Andromache claimed before, and that Hermione's fears might not be so exaggerated. ${ }^{42}$

As noted above, Hermione and Andromache are the opposites of each other in several respects, and it is not only Andromache who makes sure to emphasize these differences, but also Hermione. She does everything to show her superiority: she wears highly ornamented garments and jewellery, ${ }^{43}$ brags about the wealth of her family and the high value of her dowry. She presents herself as proud and somewhat independent, but her main fear is that Andromache will steal her position in the oikos of Neoptolemus. In her argument, Hermione employs commonplaces against barbarians. ${ }^{44}$ Although her accusations are very exaggerated and Andromache easily rebuts them in her answer, at their core some of the fears of the young wife are justifiable. If she really is barren, that can be a major problem in her relationship with her husband, and as it later in the play becomes more obvious, Andromache does have a surprisingly strong position in the palace. ${ }^{45}$ Presumably, in the root of Hermione's jealousy there is the realisation that Andromache somehow is much more likeable than she is. Instead of calming her, Andromache reproaches Hermione due to her general behaviour as a wife. She makes herself the example of a good spouse, she claims that her marriage with Hector was an ideal one, and that she also behaves in a way that pleases her new master. In the literary tradition, Andromache is an archetypical wife, and the Andromache of the tragedy readily embraces the role she has in the literary tradition. She blames Hermione for not being pleasant and obedient enough, for boasting with her birth, and for keeping her bonds too tight with her father.

Andromache uses language that does not befit her slave status, ${ }^{46}$ and sometimes her wording makes her statements ambiguous. One example of this ambiguity is her use of social deictic expressions, most of all posis. Prototypically the anchor of social deictic expressions is the speaker, and in this case, there is no need for the personal pronoun. If the anchor is the listener, or a third person, it is usually marked somehow, or is unmistakeable from the context. ${ }^{47}$ There are examples in which Andromache uses the

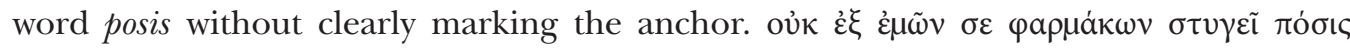

41 There are several passages in which these words are used. Stevens collects all the examples at Stevens (1971: ad 35).

42 Seaford (1990: pp. 104-106).

43 On the visual contrast between the two women see Burnett (1971: pp. 133-135); Allan (2000: pp. 58-59). On the different spaces they occupy on stage see Skouroumouni Stavrinou (2014: pp. 394-400).

44 On these topics see Hall (1989: pp. 160-201), on barbarians in Euripides see Papadomia (2010: pp. 13-16; 18-21).

45 For example, she eats at the same table with Neoptolemus which is not a common thing to do for slaves.

46 She makes it explicit in the beginning of her rhesis. On not conforming to her status in the household of Neoptolemus see Torrance (2005) and Vester (2009: pp. 296-297).

47 Schuren (2015: pp. 67-90). 


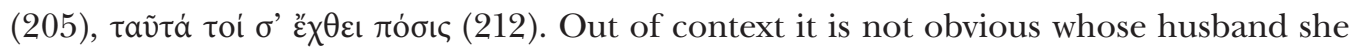
talks about, it can be either hers, Hermione's or even their common husband. This ambiguity might add to Hermione's already existing fears, although I do not claim that it is intended to be a conscious choice of wording on Andromache's part. It is more of a technique which works on the level in which the playwright communicates with the

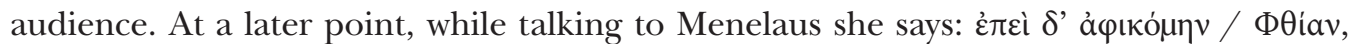

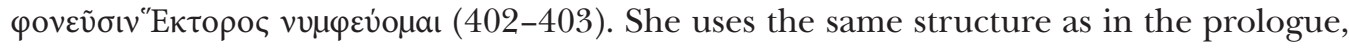
only now the passive participle is changed to a finite verb in the medium voice, meaning unambiguously 'to marry'. Her way of speaking with Menelaus portrays her as someone who does not assimilate herself to the role of a humble slave: she is proud and witty, and she does not want to arouse sympathy anymore. The episode in which Menelaus tricks her is important also for evaluating the boy's status. When realising that she needs to sacrifice herself to save his son, ${ }^{48}$ Andromache says good bye to him and asks him, that when his father comes home, tell him what has happened (415-418). This is the first time she calls Neoptolemus the father of the boy, and in the imagined scene Neoptolemus embraces and kisses his son when he arrives. This scene shows a happy family: father, mother and son, without a place for Hermione. ${ }^{49}$

My last point is that Peleus at last does indeed come to the rescue of Andromache. She was right to expect that, and by this fact it becomes clear that at the core of the tragedy there is a conflict between the house of Atreus and the family of Peleus. ${ }^{50}$ Marriage should be the most effective way to unite two families, but in the case of Neoptolemus and Hermione the marriage itself is failing, and the ties that were established by it prove to be too loose to keep the alliance between the two families. The conflict between the family of Peleus and that of Menelaus arises from Hermione's inability to bear a child and her jealousy towards Andromache, but it is deepened by the lack of a shared set of values between the two parties. The moral codes by which Peleus conducts his affairs are those of the Homeric epics while Menelaus and Hermione represent views especially of marriage, which, to some extent (when they are not outright immoral), ${ }^{51}$ resemble fifth century customs, and are alien to epic poetry. As it becomes apparent in the rescue scene, there is a deeper understanding between Peleus and the slave Andromache, who herself conforms to the moral values of the heroic world, than between the two kings. The conflict between Hermione and Andromache is not just their personal quarrel, but also a clash of different mind sets of different historic eras and different moral principles.

48 At the beginning, she does not know yet that Menelaus will trick her into leaving the altar and that he is planning to kill her son anyway.

49 The world of the plays is not that of contemporary Athens, but it should also be considered that in Athenian society bringing one's concubine or hetaira under the same roof with the wife was a serious insult against the wife and could have been ground for divorce.

50 Belfiore (2000: pp. 81-100); Philippo (1995: pp. 360-362).

51 In this respect, it might be important that they are Spartans. Some critics understand the play as a tirade against Sparta, see especially Kitto (1939: pp. 129-135), Conacher (1967: p. 167). On Peleus' rhesis against Sparta see also McClure (1999: pp. 191-192). For a discussion in relation to the play's historical context see Allan (2000: pp. 149-160). 
Andromache's arguments and pleas do not have any effect on either Hermione or Menelaus. Without the intervention of Peleus, they would kill her and her son. Since Neoptolemus never comes back to Phthia, it is Peleus who has the right to decide whom he regards as philos. What is clear from his reaction to Menelaus's arguments against Andromache and her son, is that he is more concerned with shared values than with Greek birth, and he does not find these common values with Menelaus and his daughter, while he sees them in Andromache. He also exhibits an anti-Spartan attitude, and blames Menelaus for the death of Achilles. For him, the main division is not so much between Phthia and Troy but between Phthia and Sparta. He claims that he was never happy about the marriage of Hermione and Neoptolemus (619-621), and even expels Hermione from his family (639). He does not accept the main argument of Menelaus, that Andromache's son is barbarian just like his mother, and, because of that, should not be an heir of Neoptolemus, and he also refutes the claim that, as a philos, Menelaus has the right to do whatever he wants to his son in law's slaves, namely Andromache. For Peleus the fact that Andromache is the mother of his grandson is more important than that she is Trojan or barbarian, she is more of a philos to him than Menelaus is. He puts an end to the debate by deciding that he will raise the child in the palace $\dot{\varepsilon} v \Phi \theta i \alpha \iota \sigma^{\prime} \dot{\varepsilon} \gamma \grave{\omega}$

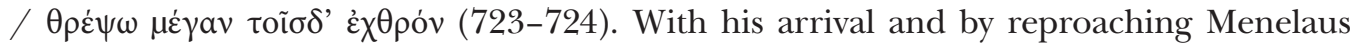
and condemning Hermione and Spartan women in general, he opts for the importance of the vertical relationship that binds him to his grandson, rather than for the horizontal one that was established by the marriage of Neoptolemus and Hermione. While in Menelaus' eyes a barbarian, and a son of a barbarian, cannot, by definition, be a Greek's philos, for Peleus it is a reasonable possibility. ${ }^{52}$

What we can see throughout the play is that philia allows for a wide range of relationships, and that the way people use the term and the concept depends on their current situation and on what they aim for. Andromache evaluates her relationship with Neoptolemus differently when she tries to evoke sympathy, and when she argues with Hermione or Menelaus. As a supplicant, she emphasizes the hopelessness of her situation, so she uses the term philos in the sense of family that excludes anybody of different origins, or of lower social status, in a sense that does not involve personal feelings. In other situations, however, she is ready to make use of the emotional aspects of the word. The two Spartans emphasize birth in order to exclude any competitors of Hermione's future children. They treat philia as something socially strictly regulated, in line with contemporary Athenian customs. In Peleus' judgement blood relations and the preservation of the family is the decisive factor. All these tensions between the families and the different ways of understanding philia cannot be reconciled even by Thetis. In the exodus, she eradicates the tensions by establishing new family relationships: Hermione has already left with a sufficient spouse, ${ }^{53}$ Andromache will remarry, this time to a Trojan. The balance will be restored, but not by solving the problems, but rather by starting everything all over again.

52 Peleus' treatment of Andromache calls to mind Achilles' treatment of Priam. Father and son both acknowledge merits in people more than they care about birth.

53 The importance of marrying inside the family or land is an Athenian notion which also occurs as a theme in Euripides' Supplicant Women. 


\section{Bibliography}

Adkins, A. W. H. (1963). Friendship and Self-Sufficiency in Homer and Aristotle. The Classical Quarterly, 13, 30-45.

Adkins, A. W. H. (1972). Moral Values and Political Behaviour in Ancient Greece. From Homer to the End of the Fifth Century. London: Chatto \& Windus.

Allan, W. (2000). The Andromache and Euripidean Tragedy. Oxford: University Press.

Belfiore, E. S. (2000). Murder among Friends. Violation of Philia in Greek Tragedy. New York - Oxford: Oxford University Press.

Benveniste, E. (1969). Le vocabulaire des institutions indo-européennes (Vol. 1). Paris: Les Éditions de Minuit.

Burnett, A. P. (1971). Catastrophe Survived. Euripides' Plays of Mixed Reversal. Oxford: Clarendon Press. Carawan, E. (2008). Pericles the Younger and the Citizenship Law. The Classical Journal, 103, 383-406.

Conacher, D. J. (1967). Euripidean Drama: Myth, Theme and Structure. Toronto: University of Toronto Press.

De Jong, I. J. F. (1991). Narrative in Drama: The Art of the Euripidean Messenger Speech. Leiden: Brill. De Jong, I. J. F (2007). Sophocles Trachinae 1-48, Euripidean Prologues, and their Audiences. In R. J. Allan, \& M. Buijs (Eds.), The Language of Literature (pp. 7-28). Leiden - Boston: Brill.

Foley, H. (2001). Female Acts in Greek Tragedy. Princeton: University Press.

Hall, E. (1989). Inventing the Barbarian. Greek Self-Definition through Tragedy. Oxford: Clarendon Press. Harrison, A. R. W. (1968). The Law of Athens. The Family and Property. Oxford: Clarendon Press.

Hooker, J. (1987). Homeric philos. Glotta, 65, 44-65.

Just, R. (1989). Women in Athenian Law and Life. London - New York: Routledge.

Kitto, H. D. F. (1939). Greek Tragedy. London: Methuen \& Co.

Konstan, D. (1985). Philia in Euripides' Electra. Philologus, 129, 176-185.

Konstan, D. (1996). Greek Friendship. The American Journal of Philology, 117, 71-94.

Konstan, D. (1997). Friendship in the Classical World. Cambridge: University Press.

Kyriakou, P. (1997). All in the Family. Present and Past in Euripides' Andromache. Mnemosyne, 50, $7-26$.

Lee, K. H. (1975). Euripides' Andromache. Observations on Form and Meaning. Antichthon, 9, 4-16.

Lévi-Strauss, C. (1969). The Elementary Structures of Kinship. Boston: Beacon Press.

MacDowell, D. M. (1978). The Law in Classical Athens. Aspects of Greek and Roman Life. New York: Cornell University Press.

Mastronarde, D. J. (2010). The Art of Euripides. Dramatic Technique and Social Context. Cambridge: University Press.

McClure, L. (1999). Spoken Like a Woman: Speech and Gender in Athenian Drama. Princeton - New York: Princeton University Press.

Mueller, M. (2001). The Language of Reciprocity in Euripides' Medea. The American Journal of Philology, 122, 471-504.

Ogden, D. (1996). Greek Bastardy in the Classical and Hellenistic Period. Oxford: University Press.

Padamitropoulos, L. (2006). Marriage and Strife in Euripides' Andromache. Greek, Roman, and Byzantine Studies, 46, 147-158. 
Papadomia, E. (2010). The Greek/Barbarian Interaction in Euripides' Andromache, Orestes, and Heracleidae. Digressus, 10, 1-42.

Patterson, C. B. (1990). Those Athenian Bastards. Classical Antiquity, 9, 40-73.

Perdicoyianni, H. (1996). Philos chez Euripide. Revue belge de philologie et d'histoire, 74, 5-26.

Philippo, S. (1995). Significant Patronymics in Euripides' Andromache. The Classical Quarterly, 45, 335-371.

Rabinowitz, N. (1984). Proliferating Triangles. Euripides' Andromache and the Traffic in Women. Mosaic. An Interdisciplinary Critical Journal, 17, 111-123.

Rabinowitz, N. (1993). Anxiety Veiled. Euripides and the Traffic in Women. Ithaca - London: Cornell University Press.

Rabinowitz, N. (1998). Slaves with Slaves. Women and Class in Euripidean Tragedy. In S. R. Joshel, \& S. Murnaghan (Eds.), Women and Slaves in Greco-Roman Culture. Differential Equations (pp. 57-69). London - New York: Routledge.

Robinson, D. (1990). Homeric Philos. Love of Life and Limbs, and Friendship with One's Thymos. In E. M. Craik (Ed.), 'Owls to Athens'. Essays on Classical Subjects Presented to Sir Kenneth Dover (pp. 97-108). Oxford: University Press.

Rubin, G. (1975). The Traffic in Women. Notes on the 'Political Economy' of Sex. In R. Reiter (Ed.), Toward an Anthropology of Women (pp. 157-210). New York: Monthly Review Press.

Schein, S. L. (1988). Philia in Euripides' Alcestis. Mètis. Anthropologie des Mondes Grecs Anciens, 3, 179-206.

Schein, S. L. (1990). Philia in Euripides' Medea. In M. Griffith, \& D. Mastronarde (Eds.), Cabinet of the Muses. Essays on Classical and Comparative Literature in Honor of Thomas G. Rosenmeyer (pp. 57-73). Atlanta: Scholars Press.

Schuren, L. (2015). Shared Storytelling in Euripidean Stichomythia. Leiden - Boston: Brill.

Scott, M. (1982). Philos, Philotes and Xenia. Acta Classica, 25, 1-19.

Seaford, R. (1990). The Structural Problems of Marriage in Euripides. In A. Powell (Ed.), Euripides, Women, and Sexuality (pp. 151-176). London - New York: Routledge.

Sealey, R. (1984). On Lawful Concubinage in Athens. Classical Antiquity, 3, 111-133.

Silver, M. (2018). Slave-Wives, Single Women and "Bastards" in the Ancient Greek World. Law and Economics Perspectives. Oxford - Philadelphia: Oxbow Books.

Skouroumouni Stavrinou, A. (2014). Inside Out. The Dynamics of Domestic Spaces in Euripides' Andromache. Hermes, 142, 385-403.

Spahn, P. (2006). 'Freundschaft' und 'Gesellschaft' bei Homer. In A. Luther (Ed.), Geschichte und Fiktion in der homerischen Odyssee (pp. 163-216). München: Verlag C. H. Beck.

Stanton, G. R. (1990). Philia and Xenia in Euripides' Alcestis. Hermes, 118, 42-54.

Stanton, G. R. (1995). Aristocratic Obligations in Euripides' "Hekabe”. Mnemosyne, 48, 11-33.

Stevens, P. T. (1971). Euripides: Andromache. Oxford: Clarendon Press.

Storey, I. C. (1989). Domestic Disharmony in Euripides' Andromache. Greece and Rome, 36, 16-27.

Storey, I. C. (2016). Andromache. In L. McClure (Ed.), A Companion to Euripides (pp. 186-202). Oxford: Blackwell.

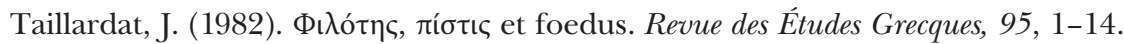

Torrance, I. (2005). Andromache Aichmalōtos. Concubine or Wife? Hermathena, 179, 39-66.

Vernant, J. P. (1979). Marriage. In Idem, Myth and Society in Ancient Greece (pp. 55-79). New York: MIT Press. 
Vester, C. (2009). Bigamy and Bastardy, Wives and Concubines: Civic Identity in Andromache. In J. R. C. Cousland, \& J. R. Hume (Eds.), The Play of Texts and Fragments. Essays in Honour of Martin Cropp (pp. 293-308). Leiden - Boston: Brill.

Wohl, V. (1998). The Intimate Commerce. Exchange, Gender, and Subjectivity in Greek Tragedy. Austin: University of Texas Press.

Kata Pártay / partaykata@gmail.com

Institute of Ancient and Classical Studies, Greek Department

Eötvös Loránd University, Faculty of Humanities

Múzeum krt. 4, 6-8, 1088 Budapest, Hungary 